\title{
Universal Jurisdiction for International Crimes - A Case Study
}

\author{
Rahim Hesenov
}

Published online: 16 December 2012

C The Author(s) 2012. This article is published with open access at Springerlink.com

\begin{abstract}
There is generally no agreed doctrinal definition of universal jurisdiction in customary and conventional international law. However, this does not preclude any definition, which embodies the essence of the concept as the ability to exercise jurisdiction irrespective of territoriality or nationality. Therefore, the concept of universal jurisdiction applies to a situation where "the nature of (an) act entitles a State to exercise its jurisdiction to apply its laws, even if the act has occurred outside its territory, has been perpetrated by a non-national, and even if (its) nationals have not been harmed by the acts."
\end{abstract}

Keywords Crime $\cdot$ Criminal code $\cdot$ Criminal law $\cdot$ Legal principle $\cdot$ Universal jurisdiction

There is generally no agreed doctrinal definition of universal jurisdiction in customary and conventional international law. However, this does not preclude any definition, which embodies the essence of the concept as the ability to exercise jurisdiction irrespective of territoriality or nationality. Therefore, the concept of universal jurisdiction applies to a situation where "the nature of (an) act entitles a State to exercise its jurisdiction to apply its laws, even if the act has occurred outside its territory, has been perpetrated by a non-national, and even if (its) nationals have not been harmed by the acts."

The issue of universal jurisdiction over the international crime of slavery and slave trading, contrary to commonly held opinion is not as straightforward as the crime of piracy. It has also been contended that the recognition of universal jurisdiction over slavery and slave trading can be traced to the Geneva Convention on the High Seas, the United Nations Convention on the Law of the Sea, the 1926 Convention To Suppress the Slave Trade and Slavery and its Protocol in 1953 and Supplementary Convention in 1956. However, there is nothing in the text of these provisions conferring States with universal jurisdiction, indeed most of the provisions direct its

R. Hesenov ( $\square)$

Xatai distirict Babak prospect, Baku, Azerbaijan

e-mail: hesrahim@rambler.ru 
obligations to the High Contracting Parties; obligations which the parties contractually agreed to and can denounce. Professor Kontorovich argues that,

"At most, international treaties on slave trading created "delegated jurisdiction" whereby several nations conveyed to one another the right to exercise some of their jurisdictional powers with respect to a particular offence, effectively making each State an agent of the others. Since such arrangements rest on State consent and the traditional jurisdiction of each State party to the agreements, they in no way...can be considered as examples of universal jurisdiction" (Kontorovich 2006).

Universal jurisdiction was applicable only to the crimes committed in terra nullius, where the jurisdiction of any other country was invalid. It has been argued that terra nullius is a requirement of universal jurisdiction, and that when sovereign power has been voluntarily ceded by treaty to grant universal jurisdiction that "in effect, the state becomes analogous to terra nullius for purposes of criminal jurisdiction. However, this analogy to terra nullius does not somehow transmute the territory of a state into terra nullius, not even by legal fiction.

The main problem of universal jurisdiction lies in the contradiction between the universality of its mission and the particularity of the political interests of the sovereign nation states which provide the statutory framework for the application of the doctrine. The paper explores the nexus between law and politics in the field of power, and might even motivate some rulers to put a stop to massive crimes.

It evaluates, inter alia, the practice of international courts that operate on the basis of ad hoc arrangements (such as the Yugoslavia Tribunal set up by the Security Council) and compares these arrangements to the structure and functioning of the newly established International Criminal Court. The paper further explores the long-term prospects of the Court in the framework of a uni-polar world order where the only superpower actively opposes the Court as organ of universal jurisdiction (Chapel Hill 1944).

With this respect Levin notes that one of the effective ways of transnational crime control is to transfer the criminal defendants to the national courts and the cases relative to genocide and military crimes included into Geneva Conventions of 1949 can be heard at the level on national courts, since international law allows universal jurisdiction of the national courts with regard to certain transnational crimes (Levin 1966).

As it was noted above, the principle of universal jurisdiction of national courts is reflected in Article VI of the 1948 Convention on the Prevention and Punishment of the Crime of Genocide. Thus, according to that legal provision, persons charged with genocide shall be tried by a competent tribunal of the State in the territory of which the act was committed, or the principle of aut judicare-aut dedere (extradite or prosecute) shall be applied. "Aut dedere aut judicare" means that States where the suspect is have the choice between extraditing or judging him. Most of the UN treaties provide for "aut dedere aut judicare" obligations, such as:

- the Tokyo Convention on Offences and Certain Other Acts Committed on Board Aircraft (1963)

- $\quad$ the Hague Convention for Unlawful Seizure of Aircraft (1970),

- the Convention on the Prevention and Punishment of Crimes against Internationally Protected Persons, including Diplomatic Agents, 1973,

- the Convention against the Taking of Hostages, 1979,

- $\quad$ the International Convention for the Suppression of Terrorist Bombing, 1997.

"Aut dedere aut judicare" means that States where the suspect is have the choice between extraditing or judging him. The application of this treaty was, for example, at the center of 
the dispute between the United States and Libya in the Lockerbie case, where the United States demanded the extradition of the suspect on the basis of the Tokyo Convention on Offences and Certain Other Acts Committed on Board Aircraft (1963), where Libya said that it did not extradite its own nationals but would rather judge them.

The Council of Europe Treaties (the European Convention on the suppression of terrorism 1977 and the European Convention on the Protection of the Environment 1998) provide for formula which are closer to "primo dedere secundo prosequi", which means that states should first extradite the suspect and, only if they cannot, should judge him. ${ }^{1}$

This principle is also reflected in Article 49 of the 1 st GC, Article 50 of the 2 nd GC, Article 129 of the 3rd GC, Article 146 of the 4th GC and paragraph 1, Article 85 of the Additional Protocol I (Bekyashev 2006).

Not only does criminal law - as law in general - require the absence of selectivity, in whichever form, in the application of the norms; of equal importance for the rule of law in any given framework, whether domestic, international or eventually supranational, is a functioning "separation of powers". The independence of the judiciary is of vital importance for the legitimacy of its decisions. This requirement, particularly in relation to a clear distinction between judicial and executive powers, has been difficult to achieve at the domestic level; it has proven to be highly problematic - in certain cases almost impossible to implement - at the transnational level where the interests of sovereign states are at stake. This has been evidenced in all projects of international trials, whether implemented or not, since the era of the First World War. In order to have any meaning at all, the doctrine of universal jurisdiction - with its implicit appeal to the conscience of mankind - requires the highest standards of separation of powers. It is based on the universal recognition of human rights and evokes ideals of justice, impartiality and fairness which are in turn related to, though not dependent upon, the preservation of peace on a global scale. Since the beginning of the twentieth century, the question has been up to what extent, if at all, the expectations raised by the proclamation of universal jurisdiction, implying the idea of universal justice, can be met under the conditions of international realpolitik. As a philosophical principle, universal jurisdiction dates back to a much earlier period than the twentieth century. The idea can be traced back to "articles of war" proclaimed in the fourteenth century. So far, virtually all examples of the exercise of universal jurisdiction have been flawed; they have simply not met the high standards set by the doctrine (Kochler 2003).

The implementation of universal jurisdiction to the cases considered as core crimes in Rome Statute of the International Criminal Court (was adopted at a diplomatic conference in Rome on 17 July 1998 and it entered into force on 1 July 2002) such as of genocide, crime against the humanity and war crimes is widely recognised. The crimes within the jurisdiction of the International Criminal Court [ICC] are listed in Article 5 thereof:

a) the crime of genocide;

b) crimes against humanity;

c) war crimes;

d) the crime of aggression. (Article 5(1)). (Rome Statute of International Criminal Court 2001).

Member States or States ratifying the Geneva Conventions are liable to implement the provisions of these Conventions. The liability related to the actions described in these articles arises irrespective of the circumstances of international or interstate conflicts.

\footnotetext{
${ }^{1}$ Information is taken from - www.ecba.org/extdocserv/conferences/madrid2009/Henzelin_ECBAApr09_ universaljurisdiction.pdf
} 
According to Artcile 11 of the Statute (jurisdiction ratione temporis), the Court has jurisdiction only with respect to crimes committed after the entry into force of this Statute. However according to Article 29 the crimes within the jurisdiction of the Court committed after 1 July 2002 (effective date of Statute according to Article 126) shall not be subject to any statute of limitations. On 16 August 1996 Azerbaijan ratified the important international agreement - Convention on the Non-Applicability of Statutory Limitations to War Crimes and Crimes against Humanity, 26 November 1968 and started to implement it under this convention to the national criminal legislation. $^{2}$

Universal jurisdiction principle also prevents the persons convicted in international crimes to ask for a political asylum or apply for a refugee status. This provision is included in paragraph 2, Article 1 of the Declaration "on Territorial Asylum" dated December 14th 1967 and into paragraph 1(e) of the Convention Relating to the Status of Refugees. As may be noted, in accordance with the universal jurisdiction principle, the persons committing the said crimes shall be prosecuted irrespective of place of crime or their personality (Lukashuk and Naumov 1999).

Matters relating to territorial and exterritorial jurisdiction within criminal law as part of the national legal system are very relevant and have great practical importance. It may be said the criminal legislation of most of the countries describe the territorial application of the principles of criminal law differently. This is due to the internationalisation of the social event, like crime, as a result of internationalisation of the social life. Therefore the internationalisation of both criminal legislation and the activities of law-enforcement agencies are necessary. We must admit that unlike the legislative and law-enforcement authorities of the states, the transnational crime adapts to the new conditions more swiftly (Lukashuk 1998).

The predicament of universal jurisdiction has always lain in the virtual impossibility of reconciling politics with law in a framework which is determined by the interplay of forces among states as primary subjects of international law. As history has shown, the problems and obstacles are manifold. Court decisions, if not backed up by the power of "willing" states, remain mere recommendations - and the "executive" support for international criminal justice always has its price in terms of the national interests of the "willing" states becoming part of supposedly purely judicial considerations. The practice of international criminal justice under the conditions of realpolitik further suffers from a serious credibility problem insofar as the interests of involved states almost unavoidably impose upon it a "judicial policy of double standards." Inconsistencies in the application of legal norms are part and parcel of the delivery of justice in the power-centered framework of relations between states. Because of the perceived "pitfalls" of universal jurisdiction - as they were articulated by Henry Kissinger, who obviously addressed the issue pro domo - political leaders have generally tended to limit its scope and tie its application to specific political circumstances, something which explains the rather erratic course of international criminal justice, including often legally inconsistent court judgments, since after the Second World War (Kissinger 2001).

Usenko notes that in the event if the exterritorial activity of the state laws conflicts with or violates the rights and legal interests of other countries, the said country cannot refer to such laws (Usenko 1996).

\footnotetext{
$\overline{2}$ Information is taken from - www.ecba.org/extdocserv/conferences/madrid2009/Henzelin_ECBAApr09_ universaljurisdiction.pdf
} 
Jurisdiction is absolute and exclusive. Territorial jurisdiction is based on the territorial principle. There are two principles of the territorial jurisdiction:

(1) Objective territorial jurisdiction principle;

(2) Subjective territorial jurisdiction principle.

According to the objective territorial jurisdiction principle, the state will have jurisdiction on the legal violations completed within its borders. In this case any part of the crime can be committed out of borders of the state. Subjective territorial jurisdiction principle is opposite to the objective territorial jurisdiction. Thus the state will have jurisdiction over the crimes started in its territory. In this case part of such crime can be committed in another country or the crime may be completed in another country. Territorial principle is the territorial reflection of the state sovereignty (Huseynov 2000).

The highly problematic nature of the exercise of universal jurisdiction - insofar as its lack of consistency and the application of double standards are concerned - has been particularly obvious in the framework of ad hoc arrangements. The "temptations of victor's justice," inherent in any power-centered form of criminal justice, have been greatest - and the most difficult to control - in the tribunals that have been set up following or in connection with armed conflicts, whether domestic or international. This has been evident in the post-World War II military tribunals, the tribunals established by the United Nations Security Council since the end of the Cold War, the courts set up on the basis of mixed domestic transnational arrangements such as those for Sierra Leone and Cambodia, as well as certain courts and tribunals that, though officially of domestic nature, are de facto set up and controlled by an occupying power (as in the case of Iraq). In all these cases, the doctrine of universal jurisdiction has been invoked in different variations, while in reality the respective arrangements of criminal justice have amounted, to a considerable extent at least, to the settling of scores by the victorious party (or parties) with the vanquished, something which has also been the case with the Security Council's ad hoc tribunals. This predicament has been eloquently articulated more than six decades ago by Judge Radhabinod Pal in his dissenting opinion in the judgement of the Tokyo Tribunal:

"It has been said that a victor can dispense to the vanquished everything from mercy to vindictiveness; but the one thing the victor cannot give to the vanquished is justice" (Judgment of Mr. Justice Pal 1946).

These developments correspond with the characterisation and increasing importance of peremptory rules in international law, the distinction between international delicts and international crimes in the context of the international responsibility of states, and the extension and fleshing out of the principle that states have a responsibility for activities originating on their territory and encroaching on the security of other states (Graefralh, 'Zur neuen QualitSt des Souveranitatsprinzips", 34 Neue Justii 1980).

At the same time, however, these developments raise difficult questions and meet with considerable obstacles in the area of criminal law, and - though they may try - states cannot minimise the difficulties by referring to outdated concepts of sovereignty. For a long time, the question of international implementation of criminal law was approached from the viewpoint of the need to prevent possible interference with state sovereignty and not from that of the need for coordinated struggle and cooperation in the fight against international crimes. Thus, states either cited the sovereignty principle as justification for objecting to the extension of universal criminal jurisdiction or as justification for rejecting the establishment of an international criminal court. This situation continues to exist today, though in a 
different fashion; there is increasing recognition that national security is at present achievable only by way of international cooperation. In this context, however, one cannot underestimate the importance of the fact that states are the essential structural elements of today's international legal order, that they represent the effective political organisational form of peoples and that they have particular protective functions which they actually exercise. However compelling the precept of cooperation may be, all states want to ensure that other states will not be permitted to use criminal law to interfere with their sovereignty or to achieve goals incompatible with the interests of the international community and peoples' right to self-determination. To date, the industrially strong Western powers have decisively opposed universal criminal jurisdiction in the context of a code of offences against the peace and security of mankind fearing that they might thereby lose rights of diplomatic protection for their citizens or be forced to recognise criminal judgments of states whose legal systems they do not wish to respect as being of equivalent right. Fundamentally, the Western powers base their position on the principle of sovereignty, that is sovereignty vis-a-vis the criminal jurisdiction of other states. They cite the principle to justify their non-recognition of foreign criminal judgments, their refusal to extradite their own citizens, and their attempts to claim immunity for persons who were acting as state agents when they committed international crimes. The Western powers do not wish national courts to be empowered to judge the conduct of foreign governments. This essentially means removing recognition of the international nature of the crimes defined in the code. ${ }^{3}$

Persons with diplomatic immunity can use the criminal legislation jurisdiction. The immunity of a diplomatic representative from the criminal jurisdiction of the receiving state was, in earlier literature, regarded as indistinguishable from his personal inviolability. At the time when the principle of personal inviolability was first clearly established, it was unusual for criminal proceedings to take place without prior arrest and detention of the accused. But as time passed and the arrest and detention of the accused was not essential for criminal proceeding, diplomatic immunity from criminal jurisdiction emerged as a separate principle of diplomatic law. As such the decision of the International Court on the case of Congo Democratic Republic against the Belgium (Democratic Republic of the Congo v Belgium) is very important. The brief overview of the case is as follows:

On 11 April 2000 an investigating judge of the Brussels Tribunal de Première Instance issued "an international arrest warrant in absentia" against Mr. Abdulaye Yerodia Ndombasi, charging him, as perpetrator or co-perpetrator, with offences constituting grave breaches of the Geneva Conventions of 1949 and of the Additional Protocols thereto, and with crimes against humanity. The arrest warrant was circulated on an international level via Interpol. On 17 October 2000, Congo filed in the Registry an Application instituting the present proceedings, in which the Court was requested "to declare that the Kingdom of Belgium shall annul the international arrest warrant issued on 11 April 2000". From the beginning the Court declared that the international law accepts the immunity of the State Officials like diplomatic and consulate agents, including heads of state, heads of government and ministers of foreign affairs from the civil and criminal jurisdiction of other countries. The Court indicated that the parties referred to number of protocols, including Vienna Convention "on Diplomatic Relations" dated 18 April 1961 and New York Convention "On Special Missions" dated 8 December 1969. Referring to the few existing decisions of national high courts, such as the Great Britain House of Lords (Pinochet case, 24 March, 1999) and the Court of Cassation in France (Qaddafi case, 13 March 2001) the Court concluded

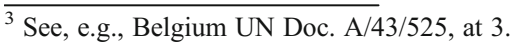


that immunity was not granted to state officials for their own benefit, but to ensure the effective performance of their functions on behalf of their respective States; and when abroad that they enjoy full immunity from arrest in another State on a criminal charge including charges of war crimes or crimes against humanity. In its Judgment, the Court found, by 13 votes to 3 ,

"that the issue against Mr. Abdulaye Yerodia Ndombasi of the arrest warrant of 11 April 2000, and its international circulation, constituted violations of a legal obligation of the Kingdom of Belgium towards the Democratic Republic of the Congo, in that they failed to respect the immunity from criminal jurisdiction and the inviolability which the incumbent Minister for Foreign Affairs of the Democratic Republic of the Congo enjoyed under international law".

Therefore, the Court found by 10 votes to 6 ,

"that the Kingdom of Belgium must, by means of its own choosing, cancel the arrest warrant of 11 April 2000 and so inform the authorities to whom that warrant was circulated". 4

I would like to note that the international court in most of its cases refers to customary norms. The Statute of the International Court of Justice interprets international custom, as "evidence of a general practice accepted as law". In order to become an international custom the norm must consist of two components: state practice (usus) and the belief that, from the objective legal point of view the practice is obligatory, forbidden or permitted depending on the character of the norm (i.e. opinio juris sive necessitatis - an opinion of law or necessity). ${ }^{5}$

According to Brownlie:

"almost all countries have the jurisdiction over the foreign citizens committing any action affecting the security of the state. This concept includes, but not limited to different political crimes. Currency, immigration and economical crimes are punished according to this rule".

The principle of protection (or security) must ensure the protection of the important interests of the state and its citizens from the criminal actions committed out of borders of the country (Brownlie 1977).

According to the international standards on human rights and freedom nobody "shall be instituted to criminal liability twice for the same crime".

However Christine van den Wyngaertt notes that the "non bis in idem" principle in respect of one person will depend on competition of jurisdictions of several states (Van Den Wyngaert and Stressens 1999).

The European Convention makes no express reference to non bis in idem but article 4 (1) of Additional Protocol 7 to the European Convention declares that,

"No one shall be liable to be tried or punished again in criminal proceedings under the jurisdiction of the same State for an offence for which he has already been finally acquitted or convicted in accordance with the law and penal procedure of that State."

However, article 4 (2) makes specific provision to re-open a case in accordance with national laws if there are new or newly discovered facts or if there has been

\footnotetext{
${ }^{4}$ Information is taken from official internet site of the International Court of Justice- http://www.icj-cij.org/ docket/index.php?p1=3\&p2=3.

${ }^{5}$ Statute of the International Criminal Court, Article 38 (1) (b). (in Turkish).
} 
serious defect in the previous proceedings, which could have affected the outcome of the case. Article 4 (2) is also flexible enough to accommodate different domestic approaches. The sub-article provides that the principle does not in any way limit the right of convicted persons to re-open of the case in circumstances permitted under national law. There are numerous cases in practice when the state grants an absolute discharge to its citizen without justification, however conviction of the same person in a different country on the basis of the universal jurisdiction shall not mean the violation of the "non bis in idem" principle, on the contrary it will play an important role in rectification of an injustice (Safarov 2004).

For example, in 1998 a Mauritanian army officer Ould Dah visited France as part of his military training. There he was arrested by the French authorities and prosecuted for acts of torture committed in Mauritania in 1990-1991. However, it must be noted that in 1993, Mauritania adopted an amnesty law which safeguarded the applicant against prosecution (Ould Dah v. France). The applicant's main complaint was that France has violated the prohibition of retroactive punishment (article 7 of the Convention of European Court of Human Rights). The Court reiterated that France has not violated any of the articles of the Convention and the applicant's complain is inadmissible. The Court observed that the United Nations Convention against Torture of 1984 (Convention against Torture and Other Cruel, Inhuman or Degrading Treatment or Punishment - UNC, 1984) was ratified by France in 1987 and had been incorporated into French law. Therefore, at the material time the "absolute necessity" of prohibiting and penalising torture in France was justified. French courts declared that they had jurisdiction to try the case in the exercise of universal jurisdiction, and also that they would apply French law. Otherwise, application of the Mauritanian amnesty law, which served merely to grant impunity to the perpetrators of torture, would deprive the universal jurisdiction (i.e. the right of States to prosecute the perpetrators of acts of torture irrespective to the place or personality) provided for by the United Nations Convention of 1984 of its substance. Like the United Nations Committee of Human Rights and the International Criminal Tribunal for former Yugoslavia, the Court considered that an amnesty law was generally incompatible with the duty on States to investigate acts of torture or barbarity. ${ }^{6}$

\section{Conclusion}

While the project of universal jurisdiction requires the highest standards of the rule of law similar to, or even higher than, those applied in any domestic constitutional system -, its predicament is revealed in the truth according to which the reality of international relations is still one of power politics, whereby relations between states are conducted on the basis of the assertion of national sovereignty. International criminal jurisdiction, for all its failings, is going to compensate for some of the weaknesses of domestic criminal jurisdiction; it is going to act in some cases where local social and political forces prevent a domestic prosecution. That will be a net gain, even if international prosecution is not possible in many cases and perhaps not even in the ones we would most like to see prosecuted. The combination of universal criminal jurisdiction of states and an international criminal court is a system which meets the criteria for effective implementation of the Code of Offences against the Peace and Security of Mankind.

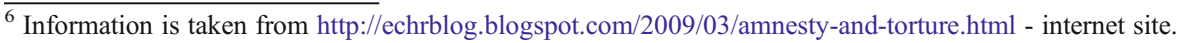


Open Access This article is distributed under the terms of the Creative Commons Attribution License which permits any use, distribution, and reproduction in any medium, provided the original author(s) and the source are credited.

\section{References}

Bekyashe,v K. A. (2006). Public international law. Collection of documents: in 2 volumes. Moscow. p.398400. (in Russian).

Brownlie, Y. (1977). International law. In 2 volumes. Book 1. Translated from English. Moscow. p.433-434. (in Russian).

Chapel Hill. (1944). Peace through Law. University of North Carolina Press, pp. 114.

Graefralh, 'Zur neuen QualitSt des Souveranitatsprinzips", 34 Neue Justii (1980/9) 395.

Huseynov, L. H. (2000). International Law Textbook. Baku. p. 84. (in Azeri.)

Judgment of Mr. Justice Pal, Member from India," in: B. V. A. Roling and C. F. Ruter (eds.), The Tokyo Judgment. The International Military Tribunal for the Far East (I.M.T.F.E.), 29 April 1946 - 12 November 1948. Volume II: Judgment of the Member from India. Opinion of the Member from the Netherlands. Amsterdam: APA - University Press Amsterdam BV, 1977, p. 1037.

Kissinger, H. A. (2001). The pitfalls of Universal jurisdiction. Foreign Affairs, 80(4), 86-96.

Hans Kochler (2003) On the normative relation between the goals of peace and security on the one hand and (criminal) justice on the other see, inter alia, the author's analysis in his 1999 Memorandum on the Yugoslav war crimes tribunal:, Global Justice or Global Revenge? International Criminal Justice at the Crossroads. Philosophical Reflections on the Principles of the International Legal Order Published on the Occasion of the Thirtieth Anniversary of the Foundation of the International Progress Organization. New York: Springer, pp. 353.

Kontorovich, E. (2006). 'The Piracy Analogy: Modern Universal Jurisdiction's Hollow Foundation', (2004) 45 Harvard International Law Journal 183; Vaughan Lowe, 'Jurisdiction'. In M. D. Evans (Ed.), International law (2nd edn., pp. 335-348). Oxford: Oxford University Press.

Levin, D. B. (1966). Liabilities of the states in the modern International Law. Moscow. p. 48. (in Russian).

Lukashuk, I. I. (1998). Exterritorial effect of criminal laws and international law. Russian Law Magazine. 1, p. 85. (in Russian).

Lukashuk, I. I., Naumov, A.V. (1999). International criminal legislation Textbook (Moscow). p. 38. (in Russian).

Rome Statute of International Criminal Court. (2001). International Law Magazine. 6, 13. (in Azeri).

Safarov, N. A. (2004). About some aspects of implementation of the "non bis in idem" principle. Azerbaijan Law Magazine. 1, 128. (in Russian).

Usenko, E. T. (1996). The problems of exterritorial effect of national legislation. Moscow International Law Magazine. № 2, p. 145. (in Russian).

Van Den Wyngaert, C., Stressens, G. (1999)The International Non Bis In Idem Principle: Resolving Some of the Unanswered Questions. International and Comparative Law Quartely. 48(4), 708. 